\title{
Vitamin D deficiency in pregnancy is not associated with diabetes mellitus development in pregnant women at low risk for gestational diabetes
}

\section{Gestasyonel diyabet açısından düşük risk taşıyan gebelerde D vitamini eksikliği ile diyabet gelişimi arasında bağlantı yoktur}

\author{
Mehmet Bal, Gülçin Şahin Ersoy, Ömer Demirtaş, Sefa Kurt, Abdullah Taşyurt \\ Tepecik Education and Research Hospital, Department of Obstetrics and Gynecology, İzmir, Turkey
}

\begin{abstract}
Objective: We aimed to investigate the effect of vitamin D deficiency as a risk factor for the development of gestational diabetes mellitus (GDM) among pregnant women without known risk factors.

Materials and Methods: The study was conducted on pregnant women who had been under regular follow-up and had low risk for GDM development. The patients were divided into two groups according to the presence of GDM; GDM and no GDM (control) group. Body mass index (BMI), sociodemographic data including level of education and nutritional habits were recorded. Serum $25(\mathrm{OH})$ vitamin $\mathrm{D}_{3}$ levels, hemoglobin, hematocrit, and mean corpuscular volume (MCV) values were measured. An oral glucose tolerance test was performed, between 24 and 28 weeks of pregnancy.

Results: GDM ratio was calculated as $4.6 \%$. The false positive rate of $50 \mathrm{~g}$ oral glucose load screening test was found to be $16.5 \%$. The BMI levels of women diagnosed as having GDM and those with no GDM group at the beginningof the pregnancy period were calculated as $24.3 \pm 2.6$ and $22.8 \pm 1.6 \mathrm{~kg} /$ $\mathrm{m}^{2}$ respectively, exhibiting a statistically significant difference between the two groups ( $\mathrm{p}=0.001$ ). Hemoglobin, hematocrit, and $\mathrm{MCV}$ values did not show a statistically significant difference between the two groups ( $\mathrm{p}>0.05)$. The levels of $25(\mathrm{OH})$ vitamin $\mathrm{D}_{3}$ of the study groups were found comparable in both groups ( $\mathrm{p}=0.13$ )
\end{abstract}

Conclusion: Plasma levels of vitamin D may not be a contributing factor for the development of GDM in women with a low risk for GDM.

Keywords: Gestational diabetes mellitus, $25(\mathrm{OH})$ vitamin $\mathrm{D}_{3}$, vitamin $\mathrm{D}$ deficiency

$\ddot{O} z$

Amaç: Gestasyonel diabetes mellitus (GDM) için bilinen risk faktörü bulunmayan gebelerde maternal plazma D vitamini eksikliğinin GDM açısından risk faktörü olup olmadığını araştırmaktır.

Gereç ve Yöntemler: GDM açısından düşük riskli olup düzenli poliklinik takiplerine gelen gebeler çalışmaya dahil edildi. GDM tanısı alan ve almayan olarak iki gruba ayrılan hastaların vücut kitle indeksi (VKI) değerleri, sosyodemografik verileri, beslenme alışkanlıkları kaydedildi. Hemoglobin, hematokrit ve ortalama eritrosit hacim (MCV) değerleri ölçüldü. Yirmi dördüncü ve yirmi sekizinci gebelik haftasında oral glukoz yükleme testi yapıldı ve serum 25 $(\mathrm{OH})$ vitamin $\mathrm{D}_{3}$ seviyeleri karşılaş̧ırıldı.

Bulgular: Çalışma grubumuzda GDM sıklığı \%4,6 bulundu. 50 gr tarama testinin yalancı pozitiflik oranını \% 16,5 olarak saptandı. Gebelik başlangıcındaki VKİ değerleri GDM tanısı alan hastalarımızda 24,3 $2,6 \mathrm{~kg} / \mathrm{m}^{2}$ iken, kontrol grubundaki gebelerde 22,8 $1,6 \mathrm{~kg} / \mathrm{m}^{2}$ tespit edildi (p=0,001). Hemoglobin, hemotokrit ve MCV değerleri kontrol ve GDM gruplarında anlamlı farklılık göstermemiştir ( $>>0,05)$. GDM grubu ve kontrol grubunda hastaların 25 (OH) vitamin $\mathrm{D}_{3}$ sirasiyla $28,5 \pm 11,6$ ve $25,4 \pm 9,3$ bulunmuştur ( $\mathrm{p}=0,13$ ).

Sonuç: Gebelik fizyolojisi normal insan fizyolojisinden farklı olduğu için ve gebelik hormonlarıyla birlikte gebeliğin fizyolojik gelişimi sürecinde insülin rezistansını etkileyecek çok faktör vardır. Çalışmamızda D vitamini düzeyi ile insulin rezistansı ve GDM gelişimi arasında herhangi bir ilişki bulunamamıştır. Anahtar Kelimeler: Gestasyonel diabetes mellitus, $25(\mathrm{OH})$ vitamin $\mathrm{D}_{3}$, D vitamini eksikliği 
PRECIS: We evaluated the effect of vitamin D deficiency as a contributing factor for the development of gestational diabetes among pregnant women who have a low risk for gestational diabetes

\section{Introduction}

Gestational diabetes mellitus (GDM) is defined as carbohydrate intolerance that appears after 24 weeks of gestation(1,2). There is increasing evidence that vitamin $\mathrm{D}$, a secosteroid synthesized in the skin, plays a vital role in the maintenance of normal glucose balance. 1, 25-dihydroxy vitamin $\mathrm{D}_{3}$ is responsible for the increase of the production and secretion of insulin and for the concurrent decrease of insulin resistance $(3,4)$.

The high prevalence of vitamin D deficiency among pregnant women is a well established. However, scientific data regarding the correlation of vitamin D with glucose balance during pregnancy and the occurrence of GDM is still insufficient and inconsistent(5). In this study, we aimed to determine whether vitamin $\mathrm{D}$ levels in maternal plasma were a risk factor for the development of GDM among pregnant women who had no other known risk factors for GDM.

\section{Materials and methods}

This cross-sectional study was conducted on pregnant women in the first trimester who were receiving antenatal care in the Aegean Obstetrics and Gynecology Education and Research Hospital in İzmir, Turkey. The study was approved by the local ethics committee of the hospital, and written consent was given by each patient. All subjects had low risk for GDM development without any other accompanying medical condition. We accepted the risk factors for GDM development as those determined by the American Diabetes Association (ADA) and the American Congress of Obstetricians and Gynecologists (ACOG)(6,7). Therefore, women with obesity, aged more than 35 years, with prior history of gestational diabetes mellitus in a previous pregnancy, and family history of diabetes mellitus were excluded. The inclusion criteria for the study were pregnant women aged between 15 and 35 years; a negative C-reactive protein value; the absence of accompanying illness that could interfere with the interpretation of diabetes (e.g. Cushing's syndrome, acromegaly); a medical history devoid of alcohol consumption; diabetogenic agent use (e.g. steroids); multiple pregnancy; hematological illness; and the absence of glucose in urine analysis.

One thousand four hundred pregnant women with a low risk of gestational diabetes who applied to our clinic in the first trimester of pregnancy were enrolled in the study. Sociodemographic variables, hemoglobin, hematocrit, and mean corpuscular volume (MCV) levels were all recorded. A 50 -g oral glucose load screening test was conducted between the 24th and $28^{\text {th }}$ weeks of gestation. In accordance with the guidelines recommended by the ACOG, the two-stage approach was used for the screening and diagnosis of GDM. All pregnant women with a low risk for GDM ingested a solution containing $50 \mathrm{~g}$ of sugar and venous blood samples were collected one hour later; patients whose plasma glucose levels were above $140 \mathrm{mg} / \mathrm{dL}$ were considered as abnormal. Those with abnormal results underwent a 100-g oral glucose tolerance test (OGTT) approximately 2 weeks later. Women who matched at least two of the criteria listed below were diagnosed as having GDM:

Fasting blood glucose level $\geq 95 \mathrm{mg} / \mathrm{dL}$ (5.3 Mmol/L), Blood glucose level at the 1 st hour $\geq 180 \mathrm{mg} / \mathrm{dL}$ (10 Mmol/L), Blood glucose level at the $2^{\text {nd hour }} \geq 155 \mathrm{mg} / \mathrm{dL}$ (8.6 Mmol/L), Blood glucose level at the 3 rd hour $\geq 140 \mathrm{mg} / \mathrm{dL}$ (7.8 Mmol/L). Of the 1322 patients with normal test results, 50 women were randomly selected as the control group using a simple computerized randomization chart generator. Seventy-eight patients with abnormal test results proceeded with the 100-g OGTT and 65 pregnant women were diagnosed as having GDM. Fifteen patients who did not comply with the regular follow-ups, who had an obstetric complication, and those who declared their intention to leave the research protocol were excluded from the study. Following the OGTT examination, $25(\mathrm{OH})$ vitamin $\mathrm{D}_{3}$ levels were measured and recorded for each patient, which is accepted as the most dependable form of vitamin D in reflecting the actual level of vitamin $\mathrm{D}$ in the body. All blood sampling was undertaken in the summer season because vitamin D levels show seasonal variation. In both groups, the measurement of serum $25(\mathrm{OH})$ vitamin $\mathrm{D}_{3}$ levels was performed using liquidliquid extraction with a liquid UPLC/MS/MS chromatographytandem mass spectrometer (manufacturer required). The lowest level of $25(\mathrm{OH})$ vitamin $\mathrm{D}_{3}$ without any change in serum PTH levels is $30 \mathrm{ng} / \mathrm{mL}$, thus this was accepted as the lower limit for vitamin D adequacy(8-10). Levels between 20 and $30 \mathrm{ng} / \mathrm{mL}$ were designated as borderline deficiency, and below $20 \mathrm{ng} / \mathrm{mL}$ was overt deficiency.

\section{Statistical Analysis}

The arithmetic mean, standard deviation, frequency and ratio values were used for the descriptive statistical analysis of the data. The distribution of data was checked using the Kolmogorov-Simirnov test. Normally distributed data were analyzed using the independent sample t-test, data without normal distribution were evaluated using the Mann-Whitney $\mathrm{U}$ test. Nominal data were analyzed using the Chi-square test.

\section{Results}

Following the 100-g OGTT, 65 out of the 78 pregnant women with an abnormal 50-g glucose screening test were diagnosed as having GDM as per the ACOG criteria (the false positive rate of the 50-g OGT was found $16.5 \%$ ). The GDM ratio was calculated as $4.6 \%$. Fifty of the 65 pregnant women with GDM met the inclusion criteria. The BMI of the women who were diagnosed 
as having GDM was calculated as 24.3, whereas it was 22.8 in the control group; there was a statistically significant difference between the two groups $(\mathrm{p}=0.001)$. The demographic features of both groups are summarized in Table 1 .

The levels of hemoglobin, hemotocrit, and MCV were similar in both groups ( $p>0.05)$. The level of $25(\mathrm{OH})$ vitamin $\mathrm{D}_{3}$ in patients did not exhibit a statistically significant difference between the two groups ( $p=0.13$ ). Moreover, the comparison of fish and milk consumption as well as the rate of vitamin pills use did not reveal a statistically significant difference between the groups ( $p>0.05$ ) (Table 1). In addition, our study population lived in a sunny region and all patients had normal sun exposure frequency ( $\geq 3$ day/week and $\geq 30$ minutes/day) and none were wearing strict religious clothing.

\section{Discussion}

The aim of the study was to investigate the association between vitamin D deficiency and GDM development in pregnant women at low risk for GDM. Our results showed that vitamin

Table 1. Patient characteristics and $25(\mathrm{OH})$ vitamin $\mathrm{D}_{3}$ levels

\begin{tabular}{|llll}
\hline & $\begin{array}{l}\text { GDM } \\
(\mathbf{n}=50)\end{array}$ & $\begin{array}{l}\text { Control } \\
(\mathrm{n}=50)\end{array}$ & p value \\
\hline Age, years & $30.9 \pm 3.5$ & $26.3 \pm 4.4$ & 0.001 \\
\hline Gravidity, median & 2 & 2 & NS \\
\hline BMI, kg/m ${ }^{2}$ & $24.3 \pm 2.6$ & $22.8 \pm 1.6$ & 0.001 \\
\hline Education & & & \\
\hline Pimary and secondary school & $33(66 \%)$ & $41(82 \%)$ & NS \\
\hline High school & $14(28 \%)$ & $6(12 \%)$ & \\
\hline University & $3(6 \%)$ & $3(6 \%)$ & \\
\hline Nutrition & & & \\
\hline One cup of milk daily & $33(66 \%)$ & $41(82 \%)$ & NS \\
\hline Fish consumption (twice a week) & $7(14 \%)$ & $10(20 \%)$ & NS \\
\hline Use of multivitamin pill & $47(94 \%)$ & $47(94 \%)$ & NS \\
\hline Hemoglobin (g/dL) & $11.9 \pm 1.3$ & $11.7 \pm 1.2$ & NS \\
\hline Hemotocrit (\%) & $34.4 \pm 3.6$ & $34 \pm 3.2$ & NS \\
\hline MCV (fL) & $89.0 \pm 5.4$ & $87.7 \pm 7.2$ & NS \\
\hline 25 (OH) Vitamin $\mathrm{D}_{3}$ (ng/mL) & $28.5 \pm 11.6$ & $25.4 \pm 9.3$ & NS \\
\hline
\end{tabular}

Groups according to $25(\mathrm{OH})$

Vitamin $\mathrm{D}_{3}$ levels

$>30 \mathrm{ng} / \mathrm{mL}$ (normal)

$25(50 \%) \quad 16(32 \%) \quad$ NS

20-30 ng/mL (moderate

deficiency)

$10(20 \%) \quad 18(36 \%) \quad$ NS

$<20 \mathrm{ng} / \mathrm{mL}$ (severe deficiency)

$15(30 \%) \quad 16(32 \%) \quad$ NS

Data are presented as mean \pm SD or n (\%), GDM: Gestational diabetes mellitus, BMI: Body mass index; MCV: Mean corpuscular volume; NS: Non-significant, SD: Standard devitation
D levels were not associated with the development of GDM. To the best of our knowledge, this is the first study to evaluate the effects of vitamin D levels on the development of GDM in pregnant women at low risk for GDM.

GDM is defined as the intolerance for carbohydrates starting from the $24^{\text {th }}$ week of gestation $(1,2)$. Factors that cause insulin resistance have always attracted the attention of scientists; the recent discovery of the interrelations between vitamin $\mathrm{D}$ and the cardiovascular system, immunomodulation, metabolic syndrome, autoimmunity and certain carcinomas has enhanced the popularity of vitamin D. Some studies detected that pancreatic $\beta$ cells express a vitamin D receptor, and allelic variations in genes involved in vitamin $\mathrm{D}$ metabolism suggested a role for $25(\mathrm{OH})$ vitamin $\mathrm{D}_{3}$ in the regulation of insulin secretion and glucose intolerance(11). In addition, it has been shown that vitamin D deficiency in experimental animals impaired insulin release and glucose tolerance $(12,13)$. Although deficiency of 25 $(\mathrm{OH})$ vitamin $\mathrm{D}_{3}$ levels has long been suspected as a risk factor for insulin resistance in GDM pregnancies, the association of vitamin D and GDM is still controversial. Similarly, it has been reported that increased serum iron levels might be related to GDM risk in pregnant women ${ }^{(14,15)}$. Also, a study conducted by Afkhami-Ardekani and Rashidi(16) showed that women with GDM had significantly higher levels of serum ferritin, iron, hemoglobin and MCV. In order to evaluate this factor, we also examined the MCV value, which is a robust index of iron status in pregnant women(17). The comparison of the MCV levels revealed no statistically significant difference between groups. The ADA reported the prevalence of GDM in pregnant women as $4 \%(6)$. In Turkey, the prevalence of GDM varies between $3-8 \%(18)$. In the present study, the GDM ratio was found as 4.6\%; however, all women in the study were at low risk for GDM development, thus the GDM ratio in this study does not reflect the actual incidence of GDM in Turkey.

Several previous studies demonstrated results consistent with our findings; Flood-Nichols et al.(19), Makgoba et al.,(20) Farrant et al.,(21) and Park et al.,(22) reported no association in the United States of America, the United Kingdom, India, and Korea between vitamin D deficiency and development of GDM. However, Lacroix found that maternal vitamin $\mathrm{D}$ deficiency was a risk factor for developing GDM in pregnant women in Canada(23). These studies did not evaluate the effect of vitamin D deficiency in pregnant women who were at lower risk for developing GDM. Therefore, in the studies that found a higher correlation between vitamin D deficiency and GDM, the results may have been related with other predisposing factors such as older maternal age and prior history of gestational diabetes in a previous pregnancy. In our study, these factors were excluded, thus we suggest that lower vitamin D levels had no association with development of GDM in Turkish pregnant women at low risk for gestational diabetes. Even though there is no consensus about the prophylactic vitamin D treatment for the prevention of developing GDM in higher risk women, vitamin D supplementation is essential for pregnant 
women in terms of its potentially beneficial effects. It is known that vitamin $\mathrm{D}$ supplementation therapy reduces the incidence of preterm labor, gestational diabetes, and small-for-gestationalage babies (24). There are some limitations of the study; first, the sample size was rather small because it had been designed as a prospective study. The total number of pregnant women was 1400 but only 65 developed GDM; this low ratio of GDM (+) women in the study group was thought to be caused by the inclusion of women with lower risk of GDM to the study. Secondly, we did not measure vitamin D levels in the first trimester; therefore, the influence of the variation in vitamin D levels was not evaluated.

\section{Conclusion}

The physiologic properties of the pregnancy period differ from normal female physiology and there are many factors such as pregnancy hormones that act on the emergence of insulin resistance during the physiologic development of pregnancy. Therefore, we were unable to find a direct correlation between vitamin D levels and GDM development as documented in several previous studies. New and long-term prospective studies in a broader patient series including pregnant women are needed to further clarify the precise relationship between vitamin D and GDM.

\section{Ethics}

Ethics Committee Approval: The study was approved by the Local Ethics Committee of Tepecik Education and Research Hospital, Informed Consent: A consent form was filled out by all participants., Peer-review: External peer-reviewed.

\section{Authorship Contributions}

Concept: Mehmet Bal, Sefa Kurt, Abdullah Taşyurt, Design: Mehmet Bal, Gülçin Şahin Ersoy, Ömer Demirtaş, Data Collection or Processing: Mehmet Bal, Analysis or Interpretation: Mehmet Bal, Gülçin Şahin Ersoy, Ömer Demirtaş, Literature Search: Mehmet Bal, Gülçin Şahin Ersoy, Writing: Gülçin Şahin Ersoy, Ömer Demirtaş. Conflict of Interest: No conflict of interest was declared by the authors.

Financial Disclosure: The authors declared that this study has received no financial support.

\section{References}

1. Hedderson MM, Williams MA, Holt VL, Weiss NS, Ferrara A. Body mass index and weight gain prior to pregnancy and risk of gestational diabetes mellitus. Am J Obstet Gynecol 2008;198:409.

2. Bianco AT, Smilen SW, Davis Y, Lopez S, Lapinski R, Lockwood CJ. Pregnancy outcome and weight gain recommendations for the morbidly obese woman. Obstet Gynecol 1998;91:97-102.

3. Chiu KC, Chu A, Go VL, Saad MF. Hypovitaminosis D is associated with insülin resistance and $\beta$ cell dysfunction. Am J Clin Nutr 2004;79:820-5.

4. Isaia G, Giorgino R, Adami S. High prevalence of hypovitaminosis D in female type 2 diabetic population. Diabetes Care 2001;24:1496.

5. Zhang MX, Pan GT, Guo JF, Li BY, Qin LQ, Zhang ZL. Vitamin D deficiency increases the risk of gestational diabetes mellitus: A metaanalysis of observational studies. Nutrients 2015;7;8366-75.
6. American Diabetes Association. Diagnosis and Classification of Diabetes Mellitus; Diabetes Care 2005;28(Suppl 1):37-42.

7. American College of Obstetricians and Gynecologists Committee on Practice Bulletins--Obstetrics. ACOG Practice Bulletin. Clinical management guidelines for obstetrician-gynecologists. Number 30, September 2001 (replaces Technical Bulletin Number 200, December 1994). Gestational diabetes. Obstet Gynecol 2001;98:525-38.

8. Tangpricha V, Pearce EN, Chen TC, Holick MF. Vitamin D insufficiency among free living healthy young adults. Am J Med 2002;112:659-62.

9. Malabanan AO, Turner AK, Holick MF. Severe generalized bone pain and osteoporosis in a premenopausal black female: Effect of vitamin D replacement. J Clin Densitometre 1998;1:201-4.

10. Lips P, Pluijm SMF, Smit JH, van Schoor NM. Vitamin D status and the threshold for secondary hyperparathyroidism in the longitudinal aging study Amsterdam. Bone 2005;36 Suppl:141.

11. Takiishi T, Gysemans C, Bouillon R, Mathieu C. Vitamin D and diabetes. Endocrinol Metab Clin North Am 2010;39:419-46.

12. Clark SA, Stumpf WE, Sar M, DeLuca HF, Tanaka Y. Target cells for 1,25 dihydroxyvitamin D3 in the pancreas. Cell Tissue Res 1980;209:515-20.

13. Bikle DD. Clinical counterpoint: vitamin D: New actions, new analogs, new therapeutic potential. Endocr Rev 1992;13:765-84.

14. Lao TT, Chan PL, Tam KF. Gestational diabetes mellitus in the last trimester: A feature of maternal iron excess? Diabet Med 2001;18:218-23.

15. Lao TT, Chan LY, Tam KF, Ho LF. Maternal hemoglobin and risk of gestational diabetes mellitus in Chinese women. Obstet Gynecol 2002;99:807-12.

16. Afkhami-Ardekani M, Rashidi M. Iron status in women with and without gestational diabetes mellitus. J Diabetes Complications 2009;23:194-8.

17. Godfrey KM, Redman CW, Barker DJ, Osmond C. The effect of maternal anemia and iron deficiency on the ratio of fetal weight to placental weight. Br J Obstet Gynaecol 1991;98:886-91.

18. Ozcimen EE, Uckuyu A, Ciftci FC, Yanik FF, Bakar C. Diagnosis of gestational diabetes mellitus by use of the homeostasis model assessment-insulin resistance index in the first trimester. Gynecol Endocrinol 2008;24:224-9.

19. Flood-Nichols SK, Tinnemore D, Huang RR, Napolitano PG, Ippolito DL. Vitamin D deficiency in early pregnancy. PLoS One 2015;10:e0123763.

20. Makgoba M, Nelson SM, Savvidou M, Messow CM, Nicolaides K, Sattar N. First-trimester circulating 25-hydroxyvitamin D levels and development of gestational diabetes mellitus. Diabetes Care 2011;34:1091-3.

21. Farrant HJ, Krishnaveni GV, Hill JC, Boucher BJ, Fisher DJ, Noonan $\mathrm{K}$, et al. Vitamin D insufficiency is common in Indian mothers but is not associated with gestational diabetes or variation in newborn size. Eur J Clin Nutr 2009;63:646-52.

22. Park S, Yoon HK, Ryu HM, Han YJ, Lee SW, Park BK, et al. Maternal vitamin D deficiency in early pregnancy is not associated with gestational diabetes mellitus development or pregnancy outcomes in Korean pregnant women in a prospective study. J Nutr Sci Vitaminol (Tokyo) 2014;60:269-75.

23. Lacroix M, Battista MC, Doyon M, Houde G, Ménard J, Ardilouze JL, et al. Lower vitamin D levels at first trimester are associated with higher risk of developing gestational diabetes mellitus. Acta Diabetol 2014;51:609-16.

24. Sablok A, Batra A, Thariani K, Batra A, Bharti R, Aggarwal AR, et al. Supplementation of vitamin D in pregnancy and its correlation with feto-maternal outcome. Clin Endocrinol (Oxf) 2015;83:536-41. 